\title{
Some properties for a general integral operator
}

\section{ADRIANA OPREA and DANIEL BREAZ}

\section{ABSTRACT.}

For certain classes of analytic functions in the open unit disk $U$, we study some convexity properties for a new general integral operator. Several corollaries of the main results are also considered.

\section{REFERENCES}

[1] Breaz, D., Owa, S. and Breaz, N., A new integral univalent operator, Acta Univ. Apul., 16 (2008), 11-16

[2] Breaz, D. and Stanciu, L., Some properties of a general integral operator, Bulletin of the Transilvania University of Braşov, Series III: Mathematics, Informatics, Physics, vol 5 (54) 2012, Special Issue: Proceedings of the Seventh Congress of Romanian Mathematicians, 67-72, published by Transilvania University Press, Braşov and Publishing House of the Romanian Academy

[3] Merkes, E. P. and Wright, D. J., On univalence of certain integral, Proc. Amer. Math. Soc., 27 (1971), 97-100

[4] Owa, S. and Srivastava, H. M., Some generalized convolution properties associated with certain subclasses of analytic functions, J. Inequal Pure Appl. Math., 3 (2002), No. 3, 1-13

[5] Pascu, N. N., and Pescar, V., On the integral operators of Kim-Merkes and Pfaltzgraff, Mathematica, 32 (55) (1990), No. 2, 185-192

[6] Pescar, V., On some integral operations which preserve the univalence, Punjab Univ. J. Math. (Lahore), 30 (1997), $1-10$

[7] Pfaltzgraff, J. A., Univalence of the integral of $f^{\prime}(z)^{\lambda}$, Bull. London Math. Soc., 7 (1975), No. 3, 254-256

[8] Ronning, F., Integral reprezentations of bounded starlike functions, Ann. Polon. Math., LX, 3 (1995), 289-297

[9] Silverman, H., Convex and Starlike Criteria, Int. J. Math. Sci., 22 (1999), 75-79

[10] Stanciu, L., Some properties for a new integral operator on the classes $S_{\lambda}^{*}(b)$ and $C_{\lambda}(b)$, An. Univ. Oradea Fasc. Mat., 20 (2013), No. 1, 137-141

[11] Stanciu, L., Some properties for two integral operators, Bul. Stiinţ. Univ. Piteşti, Ser. Mat. Inform., (2012), No. $18,93-102$

[12] Uralegaddi, A., Ganigi, M. D. and Sarangi, S. M., Univalent functions with pozitive coefficients, Tamkang J. Math., 25 (1994), No. 3, 225-230

\author{
DEPARTMENT OF MATHEMATics \\ UNIVERSITY OF PITEŞTI \\ TÂRgul diN VAle 1, 110040 PITEŞTI, ARgEŞ, ROMÂNIA \\ E-mail address: adriana_oprea@yahoo.com \\ DePARTMENT OF MATHEMATics \\ "1 DeCEMbrie 1918" University OF Alba IUlia \\ N. IORGA 11-13, 510009 Alba IUlia, Alba, RomÂnia \\ E-mail address: dbreaz@uab.ro
}

Received: 25.01.2014; In revised form: 09.09.2014; Accepted: 16.09.2014

2010 Mathematics Subject Classification. 30C45, 30C75.

Key words and phrases. Analytic functions, integral Operators, general Schwarz Lemma, convex,order.

Corresponding author: Adriana Oprea; adriana_oprea@yahoo.com 